\title{
Significance of Serum Thyrotropin and Plasma Dopamine Concentration in the Regulation of Thyroid Function in Elderly Subjects
}

\author{
TORU MORI ${ }^{1,2)}$, Toshihiko YOKOTA ${ }^{1)}$, TAKAShi AKAMIZU ${ }^{1)}$, \\ Daisuke INOUE ${ }^{1)}$, Masumi MIYAMOTO ${ }^{1)}$, Shinji KOSUGI ${ }^{1)}$, \\ KAZUYOSHI NISHINO ${ }^{1)}$, Hideo SUGAWA ${ }^{1)}$, \\ Hirotoshi NAKAMURA ${ }^{1)}$ MASAAKI NAMIKAWA ${ }^{3)}$ \\ AND HIROO IMURA ${ }^{1)}$
}

\author{
Second Division of Internal Medicine ${ }^{1)}$ and Clinical Molecular Biology ${ }^{2)}$, \\ Kyoto University School of Medicine, Kyoto 606, Japan \\ Department of Medicine and Geriatrics ${ }^{3)}$, Kyoto Katsura Hospital, Kyoto, Japan
}

\begin{abstract}
In our previous study, we observed a tendency towards an age-related increase in the serum thyrotropin (TSH) concentration. Regulatory mechanisms of TSH secretion in elderly subjects were studied. In 43 elderly subjects, serum TSH did not correlate significantly with serum $\mathrm{T}_{4}, \mathrm{~T}_{3}$ free $\mathrm{T}_{4}$ or $\mathrm{rT}_{3}$. Further, those with increased TSH $(>5 \mathrm{mU} / 1,9$ subjects) did not overlap with those with low $\mathrm{T}_{3}(<0.92 \mathrm{nmol} / 1,8$ subjects $)$. Increases in serum TSH were not associated with the presence of circulating anti-thyroid autoantibodies.

A TRH test using a $500 \mu \mathrm{g}$ single bolus injection was performed in 15 subjects. TSH response (basal: $1.92 \pm 1.42$ (s. d.) $\mathrm{mU} / 1$, peak : $11.25 \pm 5.33$ $\mathrm{mU} / 1, \quad \Sigma: 26.74 \pm 12.89 \mathrm{mU} / 1$, respectively) did not differ significantly from that of younger subjects. $\mathrm{T}_{3}$ response after $\mathrm{TRH}$ varied greatly and a close correlation was observed between basal $\mathrm{T}_{3}$ and peak $\mathrm{T}_{3}(\mathrm{r}=0.86)$, and also between peak $\mathrm{T}_{3}$ and $\Delta \mathrm{T}_{3}(\mathrm{r}=0.81)$. A significant correlation was observed between $\Sigma$ TSH and basal $\mathrm{T}_{3}(\mathrm{r}=0.60)$. Neither plasma cortisol, epinephrine nor norepinephrine concentrations showed any significant correlation with basal and TRH-stimulated TSH or $\mathrm{T}_{3}$ concentrations. However, the plasma dopamine concentration correlated significantly with $\sum \mathrm{TSH}(\mathrm{r}=0.60)$ and basal $\mathrm{T}_{3}(\mathrm{r}=0.52)$, respectively.

In conclusion, the increase in serum TSH observed in elderly subjects was felt to represent a physiological adaptation to maintain serum T3. Low $\mathrm{T}_{3}$ subjects appear to have a disturbance in this mechanism, with decreased TSH and $T_{3}$ response to TRH stimulation. The details of this disturbance have not been clarified, but a possible dopaminergic mechanism was suggested by the decreased plasma dopamine concentration observed in the low $\mathbf{T}_{3}$ group.
\end{abstract}

Received February 3, 1988

Correspondence and reprint requests to :

TORU MORI, M. D. Clinical Molecular
Biology, Kyoto University School of Medicine 54-Shogoin Kawaharacho, Sakyoku, Kyoto 606, Japan 
An age-related decrease in the serum 3, $5,3^{\prime}$-triiodothyronine $\left(\mathrm{T}_{3}\right)$ concentration has been regarded as a possible factor in the process of aging and the development of senile dementia (Levy 1962, Klug \& Adelman 1979, Nishikawa et al., 1984). In order to better clarify the role of $\mathrm{T}_{3}$ in certain pathological manifestations of aging, we recently studied the effect of low dose $T_{3}$ administration on elderly subjects (unpublished observation). Through this study, we observed a large percentage $(22 \%)$ of elderly subjects with increased serum TSH. The mechanism and significance of this TSH increase in elderly subjects is unknown. There have been quite a few reports on the serum TSH concentration and its significace in elderly subjects; however, no conclusive evidence has been demonstrated until now (Lemarchand-Beraud and Vennoti 1969, Mayberry et al., 1971, Bonnyns et al., 1972, Ohara et al., 1974, Cuttelod et al., 1974, Wenzel et al., 1974, Tunbridge et al., 1977, Sawin et al., 1979, Sowers et al., 1982, Harman et al., 1984).

The present study deals with the analysis of increased serum TSH in elderly subjects in relation to various factors which have been known to affect TSH secretion, and demonstrates a disturbance in the regulation of thyroid function in elderly subjects, especially in those with low serum $\mathrm{T}_{3}$.

\section{Materials and Methods}

Forty-three elderly subjects $(80.9 \pm 7.8$ y. o. $)$ in an institution for aged people were studied. They were exactly the same subjects used for the previous study to see the effect of low dose $\mathrm{T}_{3}$ administration (unpublished observation). Twenty-one of them received a $25 \mu \mathrm{g}$ daily dose of $\mathrm{L}-\mathrm{T}_{3}$ (Thyronamin, Takeda, Osaka) for 4 weeks, while the rest received a placebo. Venous blood sampling was performed at 8:00 a. $\mathrm{m}$. after an overnight fast at 0,2 and 4 weeks of the study.

TRH tests were performed separately in 15 elderly subjects in the same institute. Before and $30,60,120$ and $180 \mathrm{~min}$ after a bolus i. v. injection of $500 \mu \mathrm{g}$ TRH tartrate (Hirutonin, Takeda, Osaka), venous blood sampling was carried out.

Measurement of $\mathrm{T}_{3}$, thyroxine $\left(\mathrm{T}_{4}\right), 3,3^{\prime}, 5^{\prime}$ triiodothyronine $\left(\mathrm{rT}_{3}\right)$ and free thyroxine $\left(\mathrm{fT}_{4}\right)$ was performed with commercially available radioassay kits. Serum TSH was assayed with a sensitive immunoradiometric assay kit (TSH RIA BEAD II, Dainabot Laboratories, Tokyo) which had a minimum detectability of 0.025 $\mathrm{mU} / 1$ and a normal range of 0.30 to $5.0 \mathrm{mU} / 1$, respectively (Mori et al., 1986). $\Sigma \mathrm{TSH}$ was calculated from the sum of net TSH increases at $30,60,120$ and $180 \mathrm{~min}$ after TRH administration. $\Delta \mathrm{T}_{3}$ was the maximal fractional increase in $\mathrm{T}_{3}$ calculated by subtracting basal $T_{3}$ from peak $\mathrm{T}_{3}$. Autoantibody to thyroglobulin (anti-Tg) and thyroid microsomes (anti-M) were measured by the passive hemagglutination method (Fujizoki, Tokyo) and titers of more than 1 to 80 dilution were regarded as positive. Plasma cortisol, dopamine, epinephrine and norepinephrine concentrations were kindly measured by Special Reference Laboratories Inc. (Tokyo) by RIA and liquid chromatography.

For statistical analysis the Student's $t$-test was used.

\section{Results}

The serum TSH concentration of these 43 elderly subjects did not correlate significantly with serum $T_{4}, T_{3}, \mathrm{fT}_{4}, \mathrm{rT}_{3}$ and their ratios $\left(\mathrm{T}_{3} / \mathrm{rT}_{3}\right.$ and $\left.\mathrm{rT}_{3} / \mathrm{T}_{4}\right)$, and high $\mathrm{TSH}$ subjects $(>5 \mathrm{mU} / 1,9$ subjects $)$ did not overlap with those with low $\mathrm{T}_{3} \quad(<0.92$ nmol/1, 8 subjects). Further, per os $\mathrm{T}_{3}$ administration for 4 weeks effectively suppressed the serum TSH concentration, and those with high TSH before $\mathrm{T}_{3}$ administration were not more resistant to $\mathrm{T}_{3}$ than the others (Fig. 1). Anti-Tg and Anti-M antibodies were positive in $8.6 \%$ and $14.3 \%$ of the study population, respectively. However, none of the high TSH subjects had detectable antibodies. Some antibody positive subjects had a low $T_{4}$ or $T_{3}$, but this was not 


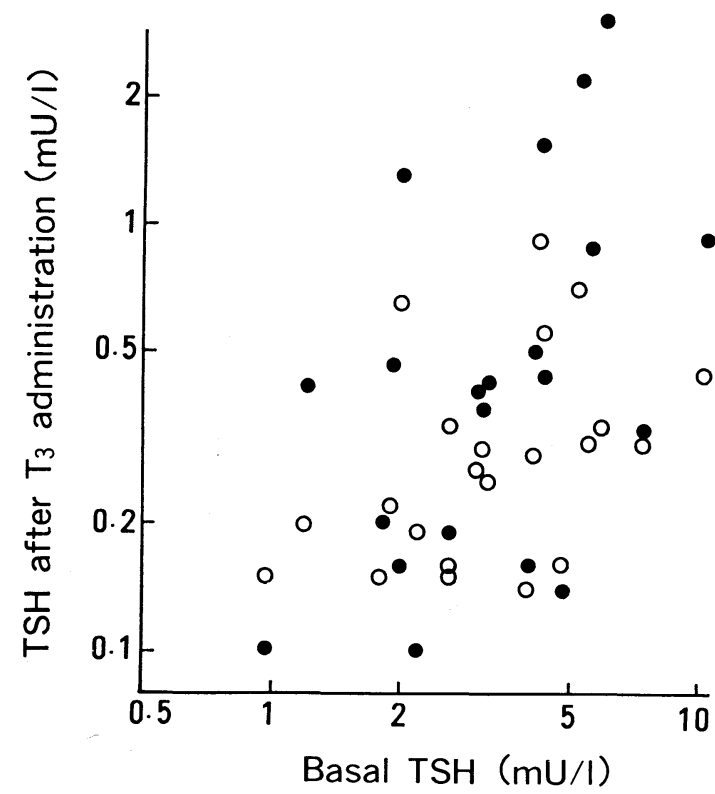

Fig. 1. Relationship between serum TSH concentrations before and after $\mathrm{T}_{3}$ administration.

Open circles stand for values obtained 2 weeks and closed circles 4 weeks after $\mathrm{T}_{3}$ administration. Overall correlation coefficient in subjects was $+0.31(\mathrm{p}<0.05)$, but those at 2 and 4 weeks $(+0.30,+0.38$, respectively) were not significant at $5 \%$ levels.

statistically significant (data not shown).

TRH tests using a $500 \mu \mathrm{g}$ bolus injection were performed in 15 elderly subjects. Fig. 2 shows the serum TSH and $\mathrm{T}_{3}$ concentrations before and after TRH. All subjects responded to TRH with a significant increase in both TSH and $\mathrm{T}_{3}$. The TSH response to TRH was delayed in many subjects, with peak TSH values at 30, 60 and 120 minutes after TRH in 5,8 and 2 subjects, respectively.

In most subjects studied, the $T_{3}$ response was also good. However, there were some poor $T_{3}$ responders and they were associated with low basal $T_{3}$. As reported previously (Ishihara et al., 1983), healthy young subjects had $\mathrm{T}_{3}$ response exceeding $0.30 \mathrm{nmol} / 1$ after TRH administration. In 5 subjects in the present study, $\mathrm{T}_{3}$ response was less than $0.30 \mathrm{nmol} / 1$. In addition, 6 of the 15 subjects had a peak $T_{3}$ concentration 120 minutes after TRH and a slight fall in $\mathrm{T}_{3}$ was seen by 180 minutes.

Table 1 summarizes the correlations among various TRH test results and the cortisol and catecholamine concentrations. Basal TSH correlated significantly with peak TSH. An excellent correlation was observed between peak TSH and $\sum \mathrm{TSH}$. Excellent correlations were observed between basal $\mathrm{T}_{3}$ and peak $\mathrm{T}_{3}$ and between peak $\mathrm{T}_{3}$ and $\Delta \mathrm{T}_{3}$. Fig. 3 shows the relationship between the basal $\mathrm{T}_{3}$ concentration and $\sum \mathrm{TSH}$ after TRH. A good correlation was observed.

Fig. 4a shows a significant correlation between the plasma dopamine concentration and $\sum \mathrm{TSH}$ after TRH, and Fig. 4b demonstrates another significant correlation between dopamine and basal $\mathrm{T}_{3}$. Those with high plasma dopamine were found to be good TSH responders to TRH and not to have extremely low basal $\mathrm{T}_{3}$. On the other hand, subjects with low basal $\mathrm{T}_{3}$ had low plasma dopamine, reduced pituitary TSH reserve and reduced thyroidal response to TRH-induced TSH.

\section{Discussion}

Previous study results of serum TSH in erderly subjects have varied, with reports of either modest or negligible incidence of TSH increase (Lemarchand-Beraud and Vennoti 1969, Mayberry et al. 1971, Bonnyns et al., 1972, Ohara et al., 1974, Cuttered et al., 1974, Wenzel et al., 1974, Sawin et al., 1979, Tunbridge et al., 1977). Most previous reports showing increased TSH in elderly subjects attributed it to an association with autoimmune thyroiditis (Bonnyns et al., 1972, Sawin et al., 1979, Turnbridge., et al., 1977) or low $\mathrm{fT}_{4}$ (Ohara et al., 1974). In the present series, we could not see any significant correlation between 

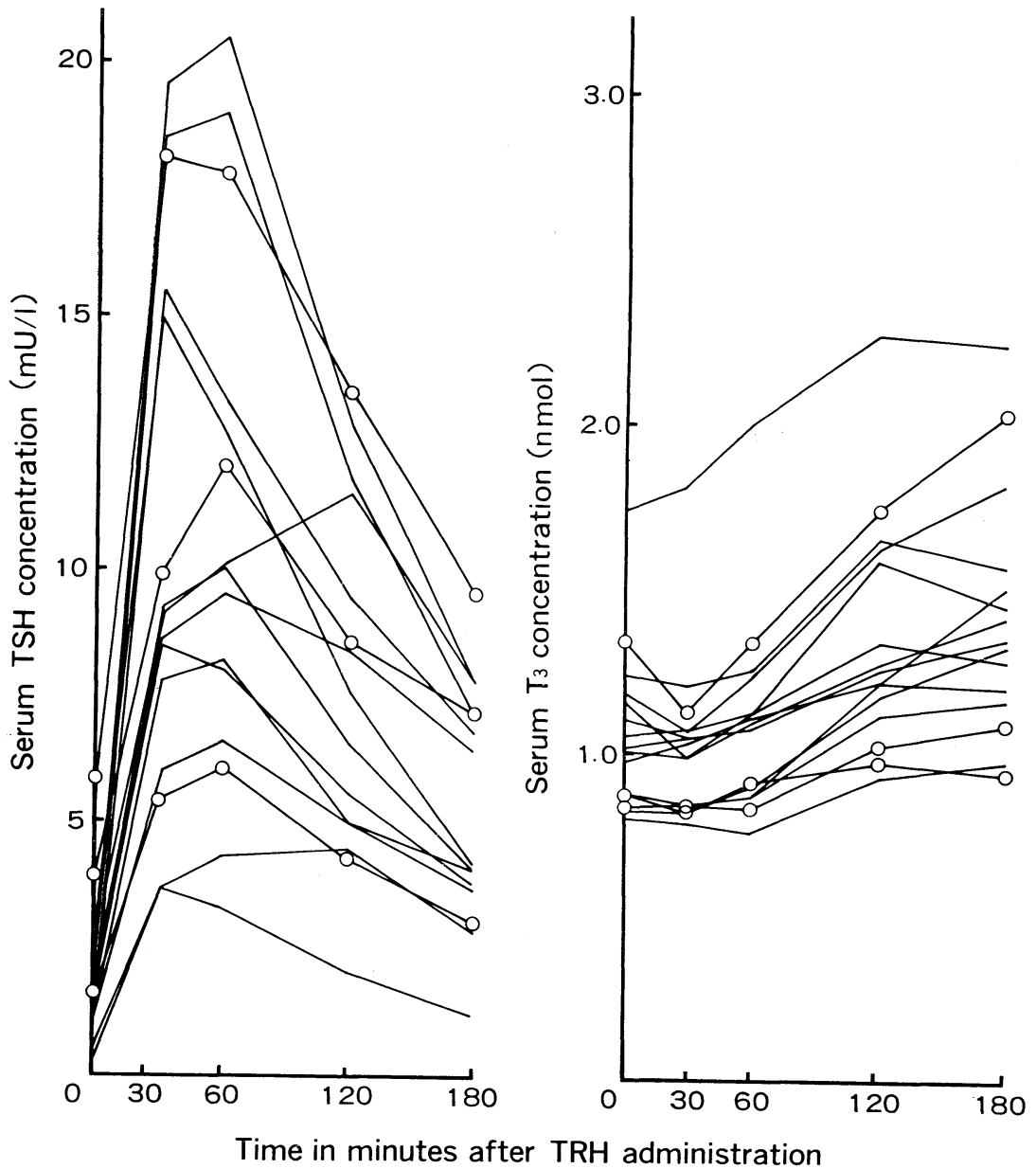

Fig. 2. Serum TSH and $T_{3}$ concentrations after TRH injection in 15 elderly subjects.

Open circles stand for male subjects and closed circles for female subjects.

Table 1. Significant correlations obtained comparing TRH test results, plasma cortisol and catecholamine concentrations.

\begin{tabular}{|c|c|c|c|c|c|c|c|c|c|c|c|}
\hline & \multicolumn{3}{|c|}{ TSH } & \multicolumn{3}{|c|}{$T_{3}$} & \multirow{2}{*}{$\begin{array}{l}\text { Corti- } \\
\text { sol }\end{array}$} & \multirow{2}{*}{$\begin{array}{l}\text { Dopa- } \\
\text { mine }\end{array}$} & \multirow{2}{*}{$\begin{array}{l}\text { Epineph- } \\
\text { rine }\end{array}$} & \multirow{2}{*}{$\begin{array}{l}\text { Norepi- } \\
\text { nephrine }\end{array}$} \\
\hline & & Basal & Peak & $2^{\mathrm{a}}$ & Basal & Peak & $\Delta^{\mathrm{b}}$ & & & & \\
\hline \multirow{3}{*}{ TSH } & Basal & & +0.564 & & & & & & & & \\
\hline & Peak & & & +0.960 & +0.605 & & & & +0.596 & & \\
\hline & $\Sigma$ & 111 & & & +0.595 & & & & +0.603 & & \\
\hline \multirow{3}{*}{$T_{3}$} & Basal & 71 & & 4 & & +0.860 & & & +0.517 & & \\
\hline & Peak & 771 & & 71 & 71171 & & +0.811 & & & & \\
\hline & 4 & 11 & & 787 & & 178 & & & & & \\
\hline \multicolumn{12}{|c|}{ Cortisol } \\
\hline \multicolumn{12}{|c|}{ Dopamine } \\
\hline \multicolumn{2}{|c|}{ Epinephrine } & & & & & & & & 7111 & & \\
\hline Norep & ephrine & 111 & 111 & 211 & 211 & 11 & 11 & 71 & 1111 & 77 & \\
\hline
\end{tabular}


serum TSH and circulating thyroid hormone or the presence or absence of autoantibodies to thyroid specific antigens. These observations suggested a disturbance in the negative feed-back regulation of $\mathrm{TSH}$, either at the level of the pituitary or CNS. Thyroid hormone unresponsiveness of the pituitary may be considered (Gershengorn and Weintraub 1975), but passive increase in serum $\mathrm{T}_{3}$ to concentrations mostly within the normal range effectively suppressed serum TSH. Further, a good correlation was observed between serum TSH before and after $\mathrm{T}_{3}$ administration. Therefore, an abnormality in thyroid hormone feed-back at the pituitary did not appear to be the cause of increased TSH.

In general, the TSH response to TRH in 15 elderly subjects could not be differentiated from that of younger healthy subjects (Mori et al., 1986), except that in

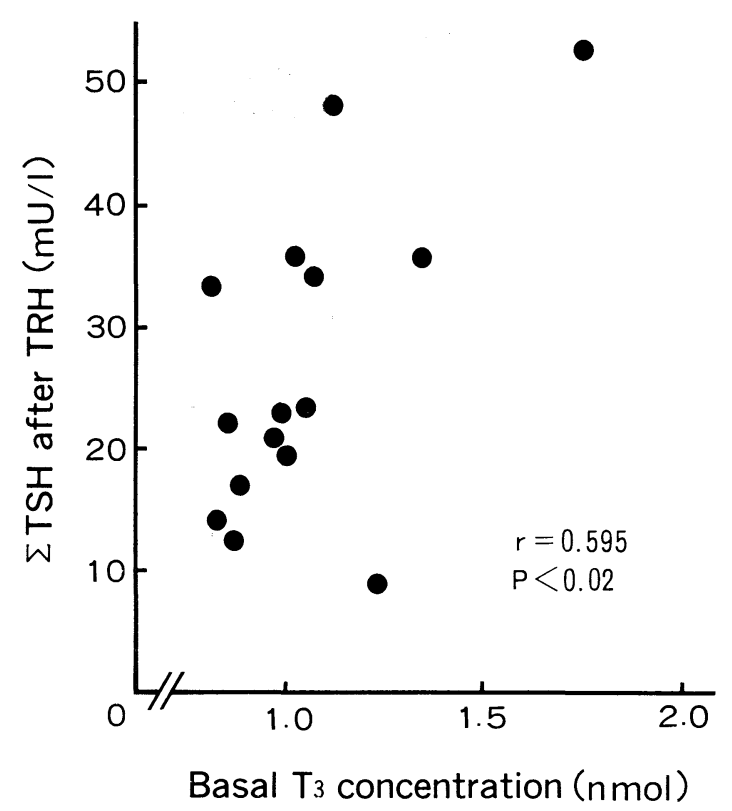

Fig. 3. Relationship between basal $\mathrm{T}_{3}$ concentration and $\Sigma$ TSH after TRH administration.

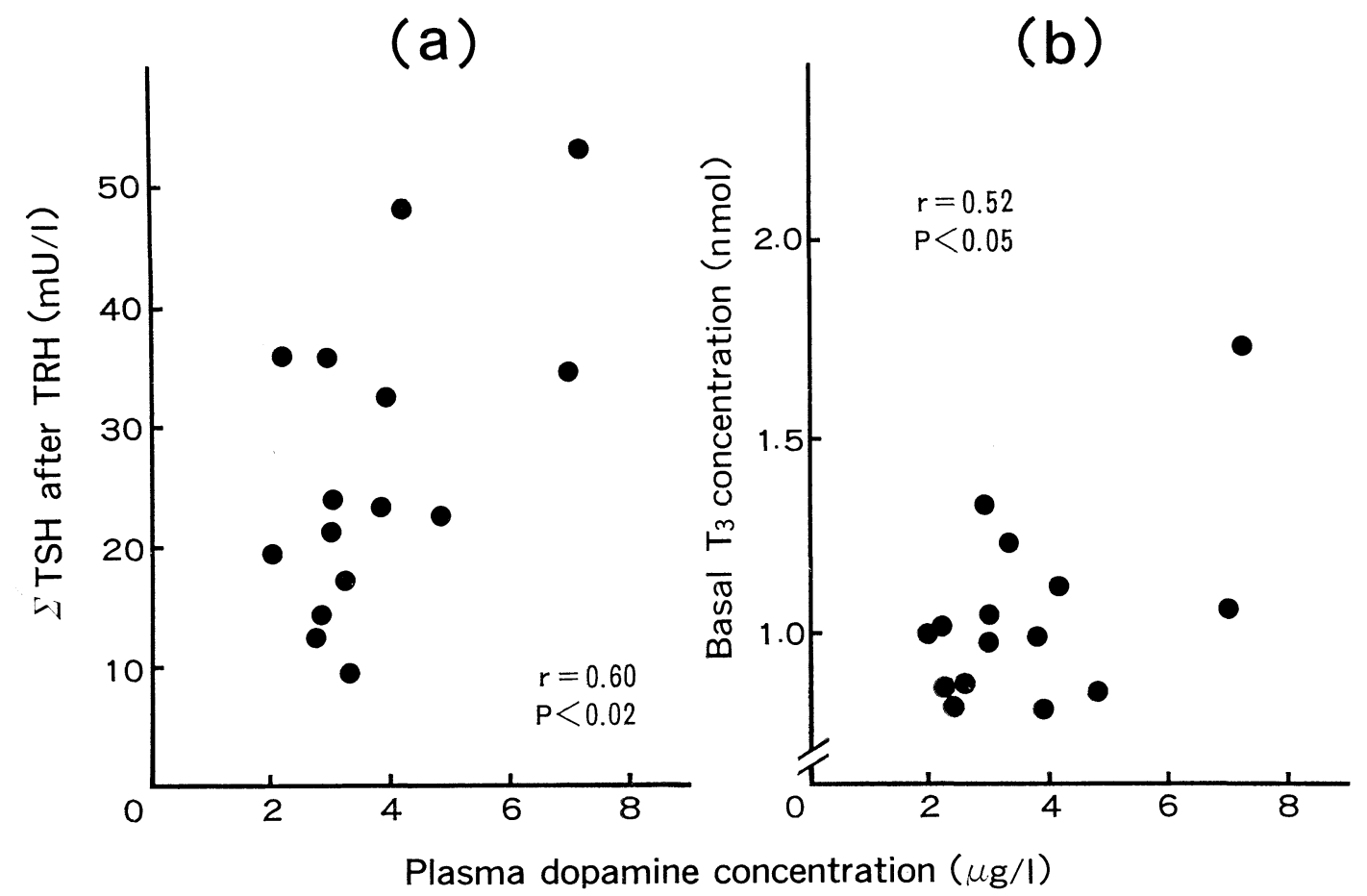

Fig. 4. Relationship between $\Sigma$ TSH after TRH (a) and basal $T_{3}$ concentration (b) with plasma dopamine concentration. 
two thirds of the elderly subjects peak TSH was observed later-at 60 or $120 \mathrm{~min}$. Ohara et al. (1974) reported exaggerated TSH response in elderly Japanese subjects, but Harman et al. (1984) observed no abnormal TSH response to TRH infusion in elderly subjects. In spite of good TSH response, the subsequent $T_{3}$ increase was not sufficient in all subjects, and 5 of them had a weaker response than $0.30 \mathrm{nmol} / 1$ which was the lowest response in young healthy subjects (Ishihara et al., 1983).

Response to exogenous TSH has been variably reported to be either less than normal or unchanged in elderly subjects (Faber et al., 1976, Sartin et al., 1977, Yamada et al., 1984). We observed a close correlation between basal $T_{3}$ and peak $T_{3}$ and also between peak $\mathrm{T}_{3}$ and $\Delta \mathrm{T}_{3}$, and a close correlation between basal $T_{3}$ and $\sum$ TSH after TRH was also observed. These findings may indicate that increased TSH is effective in maintaining the serum $\mathrm{T}_{3}$ concentration in elderly subjects.

Among cortisol and catecholamines, only dopamine was found to relate significantly with $\sum \mathrm{TSH}$ after $\mathrm{TRH}$ and the basal $\mathrm{T}_{3}$ concentration. The administration of a single dose of dopamine or the dopaminergic agonist, bromocriptine, is known to inhibit TSH secretion (Sowers et al., 1982, Hirvonen et al., 1976, Feek and Toft 1980, Scanlon et al., 1981, Cooper et al., 1983 Ishihara et al., 1985), but chronic administration of pharmacological doses of such agents neither lower the serum TSH concentration nor blunt TSH response after TRH (Hirvonen et al., 1976, Ishihara et al., 1985). Pharmacological doses of norepinephrine have also been reported to exert apparent inhibitory effects on TSH stimulated thyroid hormone release (Ahren 1986, Ahren et al., 1986). To our knowledge, however, there has been no report indicating a regulatory role of physiological levels of catecholamines in regulating pituitary TSH or thyroid functions. The age-related increase in serum TSH to- gether with hyperplasia of TSH secreting cells (Zegarelli-Schmidt et al., 1985) may induce overproduction of dopamine. Such an effect would explain the association of high plasma dopamine with high basal $\mathrm{T}_{3}$ and high $\sum$ TSH after TRH. On the other hand, decreased urinary excretion of dopamine and dopamine metabolites in Parkinson's disease (Well-Malherbe and Van Buren 1969), Alzheimer type senile demantia and Down's syndrome (Mann et al., 1980) have been reported. Although the significance is not clear, decreased dopaminergic tone may be essential to the development of senile dementia. Decreased dopamine may also diminish the pituitary TSH reserve and further reduce thyroid responsiveness to TRH stimulated $\mathrm{TSH}$, resulting in low serum $\mathrm{T}_{3}$. However, before arriving at definite conclusions based on the above findings, it seemed necessary to study a larger number of cases, because the data shown in Figs. 3 and 4 may be affected by the data for one particular patient. In addition, the observed phenomena resemble those associated with malnutrition and severe illness (Wartofsky and Burman 1982). The effects of malnutrition on thyroid functions in elderly subjects should also be considered.

\section{Acknowledgements}

The authors thank Dr. Yoshimura, the president of Kyoto Kouseien, and his staff for their collaboration, and also Dr. R. I. Dorin and Miss T. Nishimura for their assistance in preparing this manuscript.

\section{References}

Ahren, B. 1986. Thyroid neuroendocrinology : neural regulation of thyroid hormone secretion. Endocr. Rev. 7, 149.

Ahren, B., H. I. Bengtsson and P. Hender. 1986. Effects of norepinephrine on basal and thyrotropin stimulated thyroid hormone secretion 
in the mouse. Endocrinology 119, 1058.

Bonnnys, M., J-L. Pasteels, M. Herlant, L. Vanhaelst and P. A. Bastenie 1972. Comparison between thyrotropin concentration and cell morphology of anterior pituitary in asymtomatic atrophic thyroiditis. J. Clin. Endocrinol. Metab. 35, 722.

Cooper, D. S., A. Klibanoki and E. C. Ridgway 1983. Dopaminergic modulation of TSH and its subunits. Clin. Endocrinol. 18, 265.

Cuttelod, S., T. H. Lemarchand-Beraud and P. Magnenat 1974. Effect of age and role of kidneys and liver on thyrotropin turnover in man. Metabolism 23, 101.

Faber, J., T. Friis, C. Kirkegaard, U. B. Lauridsen, J. Nerup, P. Rogowski and K. Siersbaek-Nielsen 1976. Thyroid hormone response to varying doses of TSH. Acta Endocrinol. 83, 737.

Feek, C. M. and A. D. Toft 1980. Influence of thyroid status on dopaminergic inhibition of thyrotropin and prolactin secretion. J. Clin. Endocrinol. Metab. 51, 585.

Gershengorn, M. C. and B. D. Weintraub 1975. Thyrotropin-induced hyperthyroidism caused by selective pituitary resistance to thyroid hormone. A new syndrome of "inappropriate secretion of TSH". J. Clin. Invest. 56, 633.

Harman, S. M., R. E. Wehmann and M. R. Blackman 1984. Pituitary-thyroid hormone economy in healthy aging men : basal indices of thyroid function and thyrotropin responses to constant infusions of thyrotropin releasing hormone. J. Clin. Endocrinol. Metab. 58, 320.

Hirvonen, E, T. Ranta and M. Seppala 1976. Prolactin and thyrotropin responses to TRH in patients with secondary amenorrhea, the effect of bromocriptine. J. Clin. Endocrinol. Metab. 42, 1024.

Ishihara, T., T. Akamizu, K. Sawada K. Ikekubo and T. Mori 1983. Usefulness of serum T3 measurement after TRH for the diagnosis of central hypothyroidism. Folia. Endocrinol. Jap. 58, 1131.

Ishihara, T. T. Mori, N. Waseda, K. Ikekubo, T. Akamizu, and H. Imura 1985. Effect of bromocriptine on serum TSH in euthyroid patients with endocrine disorders. Endocrinol. Japon. 32, 745.

Lemarchand-Beraud, T. H. and A. Vannoti 1969. Relationships Between blood thyrotropin level, protein bound iodine and free thyroxine concentration in man under normal physiological conditions. Acta. Endocrinol. (Kbh) 60, 315.

Levy, H. 1962, Progressive age-related increase in pituitary thyrotropin level and TS iodide ratio in the rat. Endocrinology 71, 763.

Mann, D. M. A., J. Lincoln, P. O. Yates and C. M. Brennan 1980. Monoamine metabolism in Down syndrome. Lancet II, 1366.

Mayberry. W. E., H. Gharib, J. M. Bilstadt and G. W. Sizemore 1971. Radioimmunoassay for human thyrotropin. Clinical value in patients with normal and abnormal thyroid function. Ann. Intern. Med. 74, 471.

Mori, T., K. Hirano, S. Kosugi, M. Miyamoto, H. Sugawa, T. Akamizu, H. Nakamura and H. Imura 1986. Fundamental and clinical studies on sensitive TSH IRMA "TSH RIABED II" kit. Clin. Endocrinol. (Tokyo) 34, 859 (Japanese).

Nishikawa, M., M. Inada, K. Tanaka, H. Ishii and H. Imura 1984 . Relation between grade of dementia and thyroid hormone metabolism in elderly subjects. Proc 20th Annual Meeting of Jap. Soc. Clin. Metabol. p 216 (Japanese).

Ohara, H., T. Kobayashi, M. Shiraishi and T. Wada 1974. Thyroid function of the aged as viewed from the pituitary-thyroid system. Endocrinol. Jpn. 21, 377.

Sartin, J. L., J. F. Pritchett and D. N. Marple 1977. TSH, theophylline and cyclic AMP: in vitro thyroid activity in aging rats. Mol. Cell. Endocrinol. 9, 215.

Sawin, C. T., D. Chopra, F. Azizi, J. E. Mannix and P. Bacharach 1979. The aging thyroid: Increased prevalence of elevated serum thyrotropin levels in the elderly. JAMA 242, 247.

Scanlon, M.F., V. Chan, M. Heath, M. Pourmand and R. Hall 1981. Dopaminergic control of TSH, $\alpha$-subunit, $\beta$-subunit and prolactin, in euthyroidism and hypothyroidism. J. Clin. Endocrinol. Metab. 53, 360.

Sowers, J. A., R. A. Catania and J. M. Hershman 1982. Evidence for dopaminergic control of circadian variations in thyrotropin secretion. J. Clin. Endocrinol. Metab. 54, 673.

Tunbridge, W. M. G., D. C. Evered and R. Hall 1977. The spectrum of thyroid disease in a community: The Wickham survey. Clin. Endocrinol. 7, 481.

Wartofsky, L. and K. D. Burman 1982. Alterations in thyroid function in patients with 
systemic illness: The "euthyroid sick syndrome". Endocrine. Rev. 3, 164.

Well-Malherbe, H., and J. M. Van Buren. 1969. The excretion of dopamine and dopamine metabolites in Parkinson's disease and the effect of diet thereon. J. Lab. Clin. Med. 74, 305.

Wenzel, K. W., H. Meinhold, M. Herpich, F. Adlkofer and H. Schleusener 1974. TRHstimulations test mit alters-und geschlechtsabhaengigem TSH-antstieg bei normalpersonen. Klin. Wochenschr. 52, 721.

Yamada. T., M. Naka, I. Komiya, K. Ichikawa,
T. Aizawa, K. Hashizume, N. Takasu and T. Watanabe 1984. Age-related alterations of pituitary-thyroid function in normal female subjects and in female patients with simple goiter. Acta Endocrinol. 107, 346.

Zegarelli-Schmidt, E., X-R. Yu. C. M. FenoglioPreiser K. O'Toole, N. Pushparaj, G. Kledzik, D. W. King 1985. Endocrine changes associated with the human aging process: II Effect of age on the number and size of thyrotropin immunoreactive cells in the human pituitary. Hum. Pathol. 16, 277. 